\title{
Model of Slum Area Management Based on Socio-Spatial Approach. The Case of Baubau City, Indonesia
}

\author{
Dian Purnamasari ZAIN', Darmawan SALMAN², Sumbangan BAJA² \\ ${ }^{1}$ Regional Development Planning Agency of Baubau Local Government, Baubau, INDONESIA \\ ${ }^{2}$ Hasanuddin University, Graduate School of Regional Development Planning, Makassar. INDONESIA \\ E-mail: dian.purnamasariz@gmail.com, darsalman1963@gmail.com, sbjao2@yahoo.com.au \\ DOI: 10.24193/JSSP.2018.2.03 \\ https://doi.org/10.24193/JSSP.2018.2.03
}

\begin{abstract}
A B S T R A C T
The socio-spatial approach is one of alternatives in urban spatial planning studies which can be applied to discover the causes of slum settlement problems. Various slum upgrading projects have been implemented to improve the living conditions of slum dwellers. Although many previous studies have highlighted the social, economic and physical condition of slum areas, this study examines slum management in small towns from a socio-spatial perspective because there is a reciprocal interaction between social formations and spatial formations which can be measured quantitatively. It aims to analyse and develop slum settlement management model based on socio-spatial characteristics of slum settlements in Baubau City on the riverbanks, in the coastal areas and the traditional kampong type using the Fuzzy-Multi Criteria Decision Making Method (F-MCDM) and Driver-Pressure-State-Impact-Response (DPSIR). Results showed that the slum management process should be prioritized, according to the following order of significance: slums located on riverbanks as first priority, slums in the coastal areas as second priority and the traditional kampong areas as third priority.These mixed methods are practically used for developing a slum management model and can be applied directly in the formulation of government policies. This research reveals a comprehensive policy recommendation for slum management planning for each different type, according to its socio-spatial characteristics.
\end{abstract}

\section{INTRODUCTION}

The rapid growth of urban population especially due to urbanization triggers environmental, social and economic impacts to sustainable development [1]. Commonly, population growth is followed by the growth of slum areas. Based on the UN HABITAT report, population growth has been recorded worldwide in densely populated areas over the past two decades. The same source estimates that about 1.4 billion people in urban areas of the world will occupy densely populated areas by 2030 [2].

The baseline data of urban slum areas in Indonesia that was updated until 2015 showed that the percentage of the national slum area is of $10 \%$ and will be targeted to $\mathrm{O} \%$ by 2019. Baubau City, as one of autonomous regions in Southeast Sulawesi Province, has registered high population growth. Over the period of 2010-2015, the population growth was of $13.06 \%$, from 136,981 inhabitants to 151,877 inhabitants [3] with identified slum areas of 69.4 hectare based on the baseline of Program Kota Tanpa Kumuh (Cities Without Slums Program).

The implementation of slum upgrading programs in developing countries is highly dependent on the physical condition of the structures and socioeconomic conditions of the community [4], [5]. Various slum quality improvement programs have shown progress so far, however, sustainability being still a major challenge [6]. Practically, Indonesia has had 
successful experiences in improving slums, by implementing projects such as the Jakarta Kampong Improvement Program (KIP) in the 1970s [7], and more recently an Action Planning Program to Prevent and Improve the Quality of Urban Slums (Prevention Plans and Improving Urban Slum Quality / RP2KPKP) as part of City Without Slums program [8].

The implementation was strongly influenced by internal factors such as cultural perspectives [9], place of work, place of birth, home investment, type of house building and external factors, such as land ownership and government policy [10]. The program of City Without Slums is not only about facilities and infrastructures; it also addresses the problems of human and social development. This is a response to the failure of conventional approaches that emphasize physical development [11].

Difficulties in solving the problems of slum settlements in Indonesia are related to the lack of analysis of the main causes of slum area growth based on the socio-economic aspects of society. Although much qualitative research on the causes of slums has been conducted [12], [13], the formulation of slum management programs has not taken this research into account.

The transformation of socio-economic cohesion and the community as a social aspect provide great potential for the society, and also the possibility of increasing the source of program revenue [12]. Urban change is influenced by economic restructuring, which encourages people to live closer to the core of a region, representing a new link between the core and the new emerging urban areas in the region [14]. This phenomenon needs to be further studied to observe the occurrence of spatial segregation in the form of slums [15], [16].

A variety of slum upgrading projects have been implemented to improve the living conditions of slum dwellers [17]. However, the rapid dynamics of urban development poses the challenge that, in addition to dealing with existing slums, it is also necessary to prevent the emergence of new slums as a result of spatial segregation. Consequently, slums should be examined using an interdisciplinary approach, ensuring a more holistic and systematic assessment [18].

The socio-spatial approach is one of the alternatives proposed in urban spatial planning studies [19]. Based on the socio-spatial approach, more urban formation patterns are supported by the social patterns of society that shape the city life, not being a product of particular powers or business entities that have individual or group interests [20].

Urban planning management should be implemented by recognizing the positive impact of socio-spatial segregation and modifying the heterogeneity of social and economic conditions to support sub-centrality, social integration of urban space and the selection of appropriate residential locations [21]. In this study, we examined the causes of slum area development through the socio-spatial approach, resulting in the formulation of specific and appropriate priorities and policy models for slum management in Baubau City, Indonesia.

\section{THEORY AND METHODOLOGY}

\subsection{Socio-spatial approach}

One of the most important forces of urban change is the large-scale migration from rural to urban areas. It generally affects one or more economic sectors (namely trade and services) [22]. The socio-spatial characteristics play an important role in triggering the segregation of residential areas [23], [24]. The change in development policy has contributed to the separation of settlements through socio-spatial differences in the society [23], [24], [25]. Rejuvenation program policies are implemented by local governments where sociospatial differences and settlement segregation occur as a result of urban planning processes that divide urban areas based on socio-economic attributes [26], [27], [28], [29]. Socio-spatial segregation derives from the following: relationship between the shape of the city and the surrounding area (this can be categorized as an impact of urbanization), distribution of infrastructure development [11], [30], [15], value of the location of a region or region [31], affordability access to cost housing and ownership of transportation facilities, and affordability of transport costs [32]. Detailed sociospatial identification data can be used to develop a model to anticipate and predict the possible consequences of segregation [33].

\subsection{Fuzzy-MCDM and DPSIR framework}

Geospatial information management has the potential to completely change the way informal settlements are developed [34]. In selecting sociospatial indicators to be applied, researchers are limited by the nature and accessibility of data [33], [35]. If it is combined into a comprehensive socio-spatial database, it allows for spatial interventions directed to social needs that can be stratified according to scale [34]. Fuzzy Multi Criteria Decision Making (MCDM) is one application in geospatial information management [36], [37]. The integration of fuzzy logic into geospatial information systems has also been employed in various urban planning studies [38], [39], [40], [41], 42]. In addition, fuzzy logic is able to overcome multidimensional interactions, namely physical factors, nature, environment, socio-economic factors and multistakeholders who play a role in determining the criteria and alternative decisions [43], [44]. Meanwhile, policy recommendations will be developed by using the framework concept of Drivers, Pressures, States, 
Impacts and Responses (DPSIR). This framework has proved effective in simplifying and managing interactions between people and their environmental systems through multidisciplinary understanding [45], [46] as support for decision-making [47]. DPSIR's multidimensional analysis of urban expansion is able to assess the negative consequences and potential benefits of urbanization from the socio-ecological perspective, to contribute to green city management and urban sprawl control and to develop decision-making for sustainable urban development planning [48].

\subsection{Case study area}

Baubau City is geographically located in the southern part of Southeast Sulawesi Province. Baubau
City is located at $50^{\circ} 21^{\prime}-50^{\circ} 30^{\prime}$ South latitude and between $12^{\circ} 20^{\prime} 30^{\prime \prime}-12^{\circ} 20^{\prime} 45^{\prime \prime}$ East longitude on Buton Island.

The city is surrounded by a hinterland of a plain that is included in a rather steep slope class that ranges from $15 \%$ to $40 \%$; the slopes in some places are above $40 \%$ and in some others slopes are of between $2 \%$ to $15 \%$ occupied mainly by District Betoambari and District Bungi. The high slope becomes a limitation in the development of the Baubau City residential centres, especially the South, in areas with slopes above $15 \%$, which are utilized for plantations and forests. The reason for choosing this location is based on the high slum status located in the typology of the area with the priority of handling physical arrangement based on Slum Upgrading Profile of Baubau City 2015 (Fig. 1).
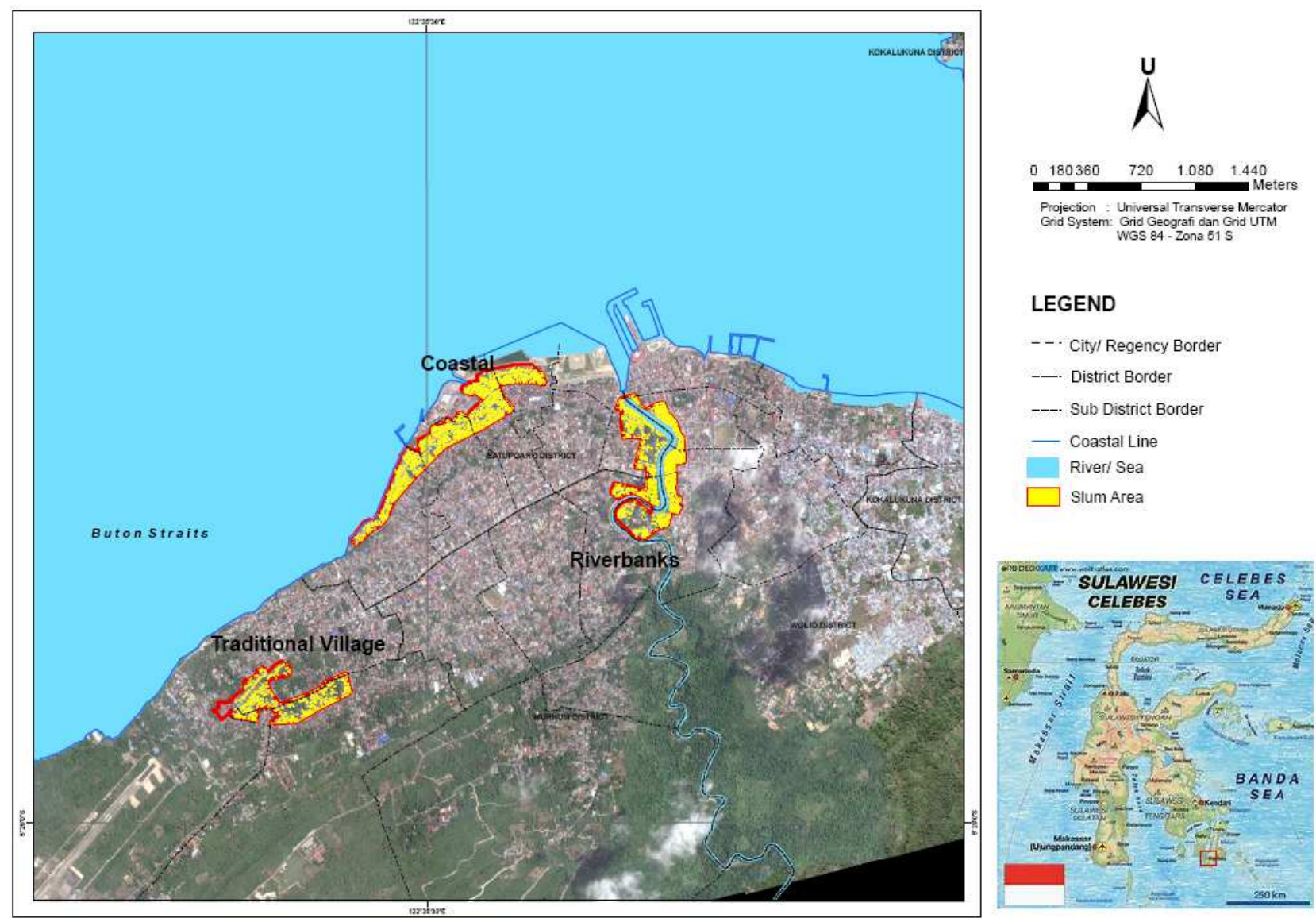

Fig. 1. Map of location study, Baubau City southeast Sulawesi, Indonesia.

The characteristics of socio-spatial areas include: 1) physical indicators and spatial patterns (variable spatial pattern, strategic area, building density, suitability of settlement land and slum development); 2) functional indicators (accessibility level, land use around slums); 3) social indicators which consist of the following variables: demographic status, economic status, and ethnic status [25], [35], [49], and phenomena socio-pathology [24], [35].

Data on physical indicators and spatial patterns were obtained from the spatial map pattern in the spatial planning plan (2014-2034), the World View-
2 image of 2016 slum profiles in 2009 and 2015, regional planning documents, settlement land maps, and planning documents of slum arrangement 2015 . Functional indicators were obtained from 2016 road status and condition maps, and land use maps of 2007 and 2016.

The analysis of these two indicators used spatial temporal (overlay) analysis with Arc GIS 10.3 ESRI Tools software, and quantitative descriptive for obtaining the dominant data characteristics. Data on social indicators were obtained through structured interviews using a survey containing demographic, 
economic, social and ethnic conditions, involving 97 heads of families as a sample of 3,331 population heads of households living in each type of area. The social indicators were analysed quantitatively using descriptive statistics by observing the dominant variables in each type of area and then a rating on the percentage of each indicator was performed. In addition, to determine the relationship between variables and reduce some of the variables into new clustered components/factors, a Principal Component Analysis (PCA) was performed on social indicator variables. PCA is a procedure for identifying a small number of uncorrelated variables, from a large set of data. Its goal is to explain the maximum amount of variance with the fewest number of principal components [50], [51].

Table 1. Fuzzy rules in membership degrees.

\begin{tabular}{|c|c|c|c|c|c|}
\hline \multirow{2}{*}{$\begin{array}{c}\text { Socio-spatial } \\
\text { indicator / variable }\end{array}$} & \multirow{2}{*}{ Sub-variable } & \multirow{2}{*}{ Unit } & \multicolumn{3}{|c|}{ Fuzzy rules (Linguistic value) } \\
\hline & & & $\begin{array}{c}\text { Low } \\
\text { priority }\end{array}$ & $\begin{array}{l}\text { Medium } \\
\text { priority }\end{array}$ & $\begin{array}{c}\text { High } \\
\text { priority }\end{array}$ \\
\hline \multicolumn{6}{|c|}{ Physical and spatial indicator } \\
\hline \multirow{2}{*}{$\begin{array}{l}\text { Land use planning } \\
\text { direction }\end{array}$} & Strategic development area & Region & $x<4$ & $4 \leq x<5$ & $x \geq 5$ \\
\hline & Spatial pattern & Type & $\mathrm{x}<1$ & $1 \leq x<2$ & $x \geq 2$ \\
\hline Level of building density & Building density & Unit/ha & $x<39$ & $39 \leq x<45$ & $x \geq 45$ \\
\hline Land suitability level & $\begin{array}{l}\text { Percentage of unsuitable land for } \\
\text { settlement development }\end{array}$ & $\%$ & $x<85.3$ & $85.3 \leq x<92.3$ & $x \geq 92.3$ \\
\hline $\begin{array}{l}\text { Level of development of } \\
\text { slums }\end{array}$ & Percentage growth of slum areas & $\%$ & $\mathrm{x}<195$ & $195 \leq x<243,5$ & $x \geq 243.5$ \\
\hline \multicolumn{6}{|l|}{ Functional indicator } \\
\hline Accessibility level & $\begin{array}{l}\text { Percentage of roads with damaged } \\
\text { conditions }\end{array}$ & $\%$ & $x<2.6$ & $2.6 \leq x<4.4$ & $x \geq 4.4$ \\
\hline Level of land use change & Settlement land use & $\%$ & $x<27,4$ & $27.4 \leq x<47.1$ & $x \geq 47.1$ \\
\hline \multicolumn{6}{|l|}{ Social indicator } \\
\hline \multirow{3}{*}{ Demography status } & Productive age structure & $\%$ & $x<67.23$ & $67.23 \leq x<69.46$ & $x \geq 69.46$ \\
\hline & Percentage of occupants $>4$ people & $\%$ & $x<56$ & $56 \leq x<60$ & $x \geq 60$ \\
\hline & Percentage $>2$ households & $\%$ & $x<3.3$ & $32.3 \leq x<41,7$ & $x \geq 41.7$ \\
\hline \multirow{8}{*}{ Economic status } & Percentage education level $<9$ years & $\%$ & $x<29.6$ & $29.6 \leq x<43.3$ & $x \geq 43 \cdot 3$ \\
\hline & Income $<$ IDR 1.500 .000 & $\%$ & $x<77.6$ & $77.6 \leq x<87.3$ & $x \geq 87 \cdot 3$ \\
\hline & Percentage of dominant occupation & $\%$ & $x<48.3$ & $48.3 \leq x<51.3$ & $x \geq 51.3$ \\
\hline & $\begin{array}{l}\text { Percentage of dominant field business } \\
\text { sector }\end{array}$ & $\%$ & $x<53.3$ & $53.3 \leq x<61.6$ & $x \geq 61.6$ \\
\hline & Average land price & $\begin{array}{l}\text { Thousa } \\
\text { nd IDR }\end{array}$ & $x \geq 1000$ & $700 \leq x \leq 900$ & $x \leq 600$ \\
\hline & Building ownership status & $\%$ & $x \geq 81.6$ & $73.3 \leq x<81.6$ & $x<73.3$ \\
\hline & Legality of building ownership & $\%$ & $x \geq 63$ & $39 \leq x<63$ & $\mathrm{x}<39$ \\
\hline & Average Hire Rates & $\begin{array}{l}\text { Million } \\
\text { IDR/ye } \\
\text { ar }\end{array}$ & $x \geq 4.4$ & $3.2 \leq x<4.4$ & $x<3.2$ \\
\hline \multirow{2}{*}{ Ethnic status } & $\begin{array}{l}\text { Status of population (percentage of } \\
\text { migrants) }\end{array}$ & $\%$ & $x<27$ & $27 \leq x<45$ & $x \geq 45$ \\
\hline & Length of stay & Years & $17 \leq x \leq 27$ & $28 \leq x \leq 37$ & $x>37$ \\
\hline \multirow{4}{*}{ Socio-pathology } & Crime level & $\%$ & $\mathrm{x}<80$ & $80 \leq x<87$ & $x \geq 87$ \\
\hline & Flood vulnerability (1-3 times per year) & Level & Low & Medium & High \\
\hline & Vulnerability of residential fire disasters & Level & Low & Medium & High \\
\hline & Vulnerability to social conflict disasters & Level & low & Medium & High \\
\hline
\end{tabular}

PCA analysis results were used to identify the social indicators that correlate with each other in shaping socio-economic constructions into three types.
The first step in PCA analysis was to find the matrix correlation between the observed indicators. There were several standards used as PCA analysis requirements 
i.e. correlation matrix between indicators, partial correlation, and Kaiser-Meyer Olkin (KMO). If three required conditions are fulfilled, then the PCA analysis software through IBM SPSS Statistics 22 can be performed with the following stages: extraction factor, factor rotation, interpretation of factors, generation of factor score, and factor scores computation [51].

The data processing results of identification of socio-spatial characteristics became the input in analysing and building the model of slum settlement management through the following stages:

1). The first stage consisted in entering the results of the analysis of socio-spatial characteristics into vector spatial data (polygon) in three types of area by filling information on tabular data of each slum area polygon. Modelling using fuzzy logic analysis can only be processed on spatial data of raster type. Therefore, vector spatial data were first converted into raster spatial data using Conversion Tools in Arc GIS 10.3 software through the Polygon to Raster extension.

2). The next step in Fuzzy logic modelling was to create the degree of membership of each criterion of socio-spatial variables that had been pre-rasterized. The membership value, degree or function is the main characteristic of reasoning with the fuzzy logic [36], [38], [52], [53]. The membership degree of each criterion is $0-1$ using the fuzzy membership extension in Arc GIS 10.3 software. The output of this stage was the raster data of each criterion that had a membership value. The method used to design the model of slum areas management with Multi Criteria Decision Making (MCDM) using Fuzzy Mamdani logic is the knowledge base represented as linguistic rules "IF ... THEN". Fuzzy logic modelling with Mamdani operator is considered appropriate for modelling social variables. The fuzzy membership function and the output of the previous variable are described in Figure 2.
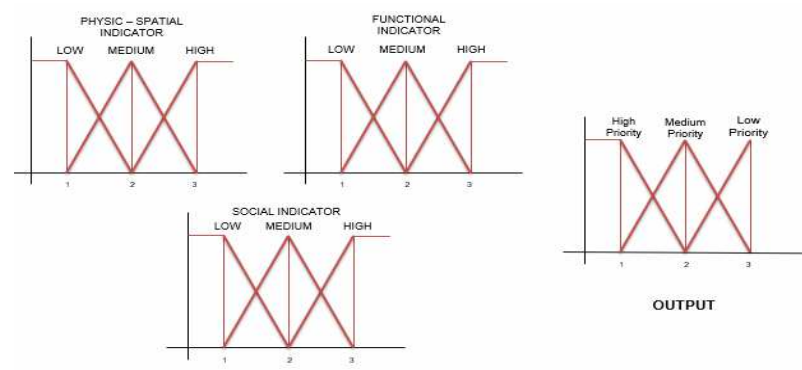

output

INPUT

Fig. 2. Fuzzy membership function.

Fuzzy rules and assumptions in membership degrees are presented in Table 1.

Fuzzy overlay was determined by entering the output of the previous stages of raster data of each criterion which had a value of 0-1. Overlays were performed on physical indicators - spatial patterns, functional indicators and social indicators. Therefore, the output of the priority map of the slum settlement area was obtained.
3). The next step was to build the Driver / Driving Factor, Pressure, State, Impact and Response (DPSIR) framework based on the Fuzzy MCDM priority mapping results. This model is a spatial-based policy action plan for the management of slums.

\section{RESULTS AND DISCUSSION}

\subsection{Socio-spatial characteristics}

\subsubsection{Slums in traditional Kampong}

The slum area of traditional kampong is a region with 4 development areas based on Land Use Plan direction, with the function of spatial pattern as housing.

This area has a building density of 33 units/ha, $95.25 \%$ of unsuitable land for settlement development and a slum growth rate of $292 \%$ over the past 5 years. Functionally, the area has $0.9 \%$ of local roads in damaged conditions, and land use settlement changes (2007-2016) of $7.7 \%$.

Socially, the area has the following characteristics: the structure of productive age (65\%), percentage of occupants $>4$ persons/occupancy (52\%), percentage $>2$ households (23\%), percentage of education level of head of family $<9$ years $(16 \%)$, income level < IDR 1,500,000 (68\%), type of work of head of family ( $45 \%$ traders), dominant business sector (45\% large and retail trade), average land price (IDR 700,000-900,000/sq m), building ownership status (90\% own), legality of building ownership (87\% have building permit), average rental houses rate (IDR 5.6 million/year), residence status (13\% migrants), length of stay (36\% of households have been living for 17-27 years), crime rates 1-3 times/year (84\%), vulnerability level of flood disaster, vulnerability of fire disaster (low), social conflict vulnerability (high).

\subsubsection{Slums on the riverbanks}

The slum area on the riverbanks is a region with 5 development areas based on Land Use Plan direction, with the function of housing, trade and services. This area has a building density of 50 units/ha, $78.3 \%$ of unsuitable land for settlement development and slum growth rate of $185 \%$ over the past 5 years. Functionally, this area has $6.2 \%$ of local roads in damaged conditions, and land use settlement changes (2007-2016) of $66.8 \%$.

Socially, the area has the following characteristics: the structure of productive age (65.4\%), percentage of occupants > 4 persons/shelter (64\%), percentage $>2$ households $/ 51 \% 9$ years ( $57 \%$ ), income level < IDR 1,500,00o (85\%), type of work of the head of family ( $55 \%$ traders), dominant business sector $(70 \%$ - large and retail trade), average land price (< IDR $600,000 / \mathrm{sq} \mathrm{m})$, building ownership status (79\% own 
property), legality of building ownership ( $55 \%$ have building permit), average rental houses price (IDR 5.3 million/year), residence status (63\% migrants), length of stay ( $45 \%$ of households have been living here for 28 37 years), crime rates 1-3 times/year (94\%), flood vulnerability (high), fire vulnerability (high), and social conflict vulnerability (high).

\subsubsection{Shums in Coastal Areas}

The coastal slum area consists of 5 development areas based on Land Use Plan direction, whose functions are housing, trade and services. This area has a density of buildings (47 units/ha), $99.37 \%$ of unsuitable land for settlement development and a slum growth rate of $146.6 \%$ over the past 5 years. Functionally, the area has $3.5 \%$ collector roads in damaged conditions, and land use settlement changes (2007-2016) of $29.4 \%$.

Socially, the area has the following characteristics: the structure of productive age (71.7\%), percentage of occupants $>4$ persons/occupancy (62\%), percentage $>2$ households/occupancy (35\%), education percentage level of head of family $<9$ years $(47 \%)$, income level < IDR 1,500,000 (97\%), type of work (50\% fishermen), dominant business sector (50\% fishery), average land price (> IDR 1 Million/sq m), building ownership status (65\% owned), legality of building ownership ( $15 \%$ have building permit), average house rent (IDR .2 million/year), residence status (9\% migrants), length of stay (41\% household has been living for > 37 years), crime rate 1-3 times/year (73\%), flood vulnerability level (low), vulnerability level of fire disaster (medium), and vulnerability of social conflict (high).

\subsubsection{Major components of social indicators}

This phenomenon was clarified through the results of PCA analysis of social indicators in which 7 variables were mutually influential and formed a group of factors that played a role in triggering social slum, i.e. component 1 consists of income, occupation, and business field; component 2 consists of the number of occupants of the house, the number of households in one building; and component 3 consists of education and legality of building ownership (building permit). Component 1 is called the economic factor, component 2 is called the demographic factor and component 3 is a factor of human resource level (Table 2).

Table 2. Results of the Principal Component Analysis.

\begin{tabular}{|l|rrr}
\multicolumn{1}{|c|}{ Rotated component Matrix } & \multicolumn{3}{c}{ Component } \\
\hline Education level & $\mathbf{1}$ & $\mathbf{2}$ & $\mathbf{3}$ \\
Income level & 0.051 & -0.234 & 0.748 \\
Number of family members (occupants) & 0.626 & -0.197 & 0.374 \\
Number of households in 1 (one) building & -0.056 & 0.903 & -0.112 \\
Occupation & -0.118 & 0.920 & 0.057 \\
Business field & 0.871 & 0.025 & 0.172 \\
Legality of building ownership & 0.837 & -0.099 & -0.184 \\
\hline
\end{tabular}

Extraction Method: Principal Component Analysis. Rotation Method: Varimax with Kaiser Normalization.

a. Rotation converged in 4 iterations.
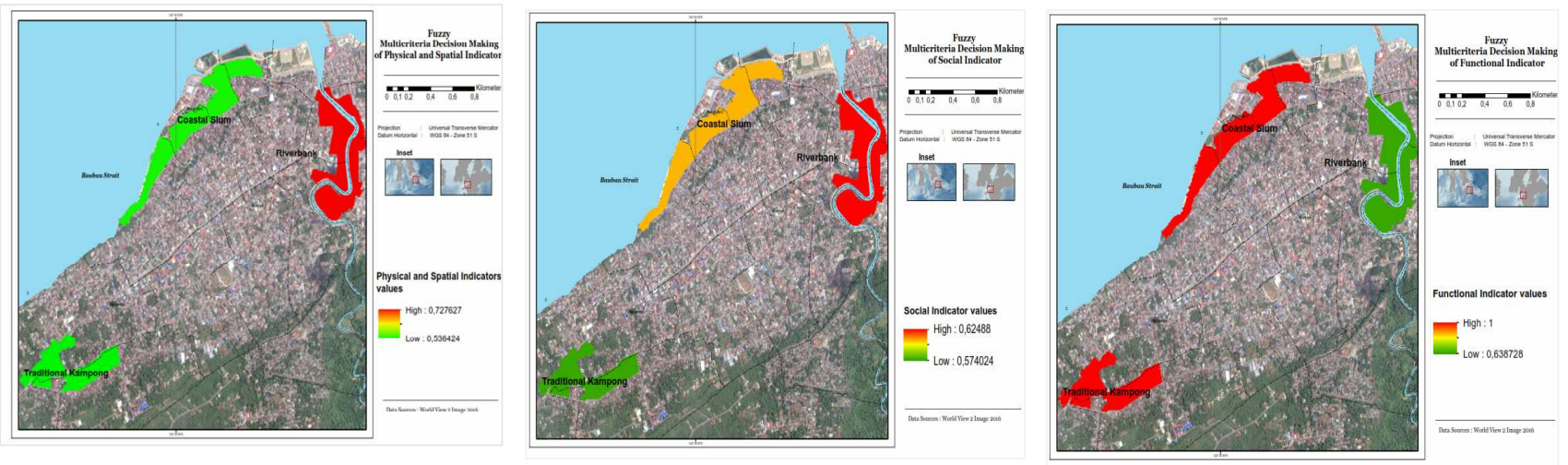

Fig. 3. Fuzzy-MCDM analysis of the three types of slums.

\subsection{Priority of slum management planning}

The priority slum areas individualized according to the physical and spatial indicators for management measures are those located on the riverbanks (score 0.727), followed by slums on coastal areas (scores 0.669) and slums located in in traditional Kampong (scores 0.536). The priority rank is different when considering the functional indicators, as follows: first priority - slums on coastal areas (score 1.0) and 
those in traditional Kampong (score 1.0) followed by the slums on the river banks (score 0.638). According to the social indicator, we found the same priority hierarchy of management, namely: slums on the riverbanks (score 0.6248) as first priority, followed by slums on the coastal areas (score 0.599) and slums in the traditional Kampong (score 0.574) (see Fig. 3).

Based on the combination of all indicators, we concluded that areas in most need to be prioritized for slum management are those on riverbanks (score o.624), followed by the coastal areas (value 0.599) and the traditional kampong areas (value 0.536) (Fig. 4).

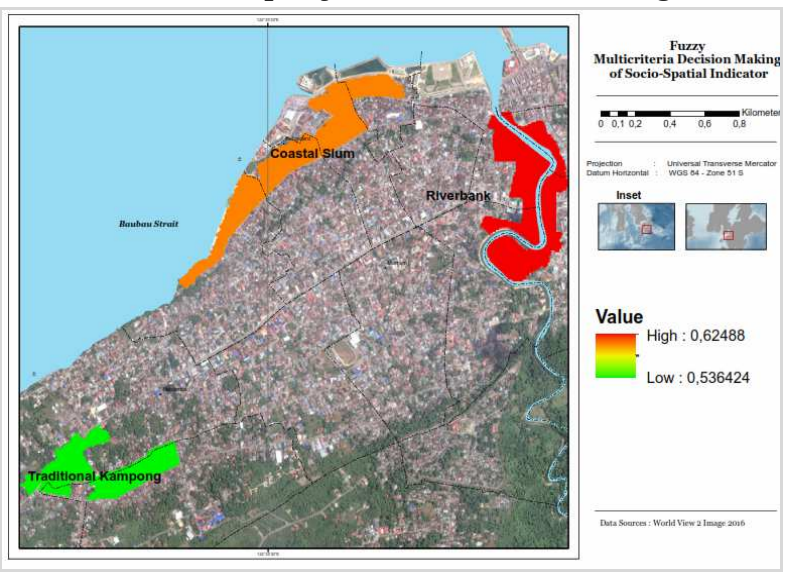

Fig. 4. Priorities of slum management model.

This research shows that using space for the development of trade and services area, has a social impact; in this case, the growth of slums can increase regional microeconomic growth.

The expansion of trade and service areas initiated by the government will ultimately be driven by the private sector. The private sector, which has large capital, will dominate the field of trade and services. However, in the case of low-income communities, this region becomes an attraction factor for them to open small-scale businesses. This pull factor also results in a high level of urbanization in trade and services. Thus, the emergence of slum areas cannot be avoided. Lefebvre (1991) described that space contained by policies and plans (master plan) often collide with the actual space conditions in the society [20]. Understanding the uniqueness of regional characteristics is crucial for building and developing policies that will decrease the negative impact of urbanization [54]. Physical and socio-economic conditions found in informal settlements are generally hazardous to health and tend to exacerbate the severe socio-economic conditions of the urban poor as well as environmental pollution and degradation of the local ecosystems [8]. Based on the results of prioritizing Fuzzy-MCDM, the slum settlement management model is formulated through the Driving Factor - Pressure State - Impact - Response framework (DPSIR
Framework) and it is described in the following subsections.

\subsection{Constructing the management model of slum areas}

Slums on the river banks are the first set priority in which indicators that play the role of drivers of slum-dwelling levels in the region are physical-spatial and social indicators. Physical factors and spatial patterns next to the city centre shaping the Central Business District (CBD) also have close access to ports and river routes. In line with the research findings of Surtiani (2006), the strategic location supported by the determination of the area as a trade and service area led to the proliferation of activities of goods and services [16]. So, this area became the attraction of urbanization as a driving factor. As Jeong (2011) pointed out, slums are prevalent in commercial centres, causing population density in these areas. Both driving factors put pressure on population density, housing demands, availability of residential land, micro, small and medium economic activities and changes in the function of area utilization [55], [44]. The condition of the area leads to the characteristics of slum areas, such as land limitations and land differences for the development of settlements, thus affecting the relatively cheap land prices but high rents so housing density is even denser. Slums on the riverbanks are inhabited by migrants who work as small retailers with a relatively low level of income and education. In addition, the percentage of migrants inhabiting this area is quite large and is dominated by a high productive age structure. As indicated by some previous findings, low-income communities tend to remain in the downtown area, due to limited access to housing in accordance with their financial capabilities [23]. Residential stability and family size significantly affect investment and increase housing demand [56]. On the other hand, rural migrants make significant contribution to the overall urban economy and the local districts where migrant settlements are located [55]. These conditions will have an impact on the deterioration of the quality of the settlement environment, the deterioration of the quality of health, the vulnerability to floods and fires, crime, poverty, social conflicts including impacts on private investment. Private investment is the power of financiers who are able to change the function of urban space [57]. Therefore, the policy and program response that can be applied in this area is the policy to give priority to residents who live in the region to obtain the assistance of ownership of residential at affordable costs either through the program of Rusunawa (Vertical dwelling/Apartment) or financing scheme for simple housing located outside this area. In addition, community empowerment, and the acceleration of 
community-based riverbanks development are expected to address social impacts in the region (Fig. 5).

Slums on coastal areas are the second priority. The functional driving factor is the level of accessibility based on road status and conditions. The social driving factor is characterized by the inability to use the function of the region, which triggers a low economic level and an increase in population. Both driving factors put pressure on population density, settlement needs, land use change, fishery port development and development of trade and service areas. These pressures have led to the conditions of high occupancy density, close kinship factors, relatively low building ownership legality, high housing density, low-rent housing, increased size of settlements, including inappropriate housing growth and high land prices. The productivity of fishermen is low although the productive age structure and education level are high. This is marked by a decline in fisheries production from 5198.6 tonnes during 2014 to 4,080 tonnes in 2016 [3]. These conditions trigger environmental degradation, declining quality of human resources, high levels of social conflicts, which are also contributing to poverty. Unlike slum settlement, the direction (response) of settlement development for fishermen in this area should be applied based on the pattern of vertical housing development such as the development of fishery apartments located in coastal areas.

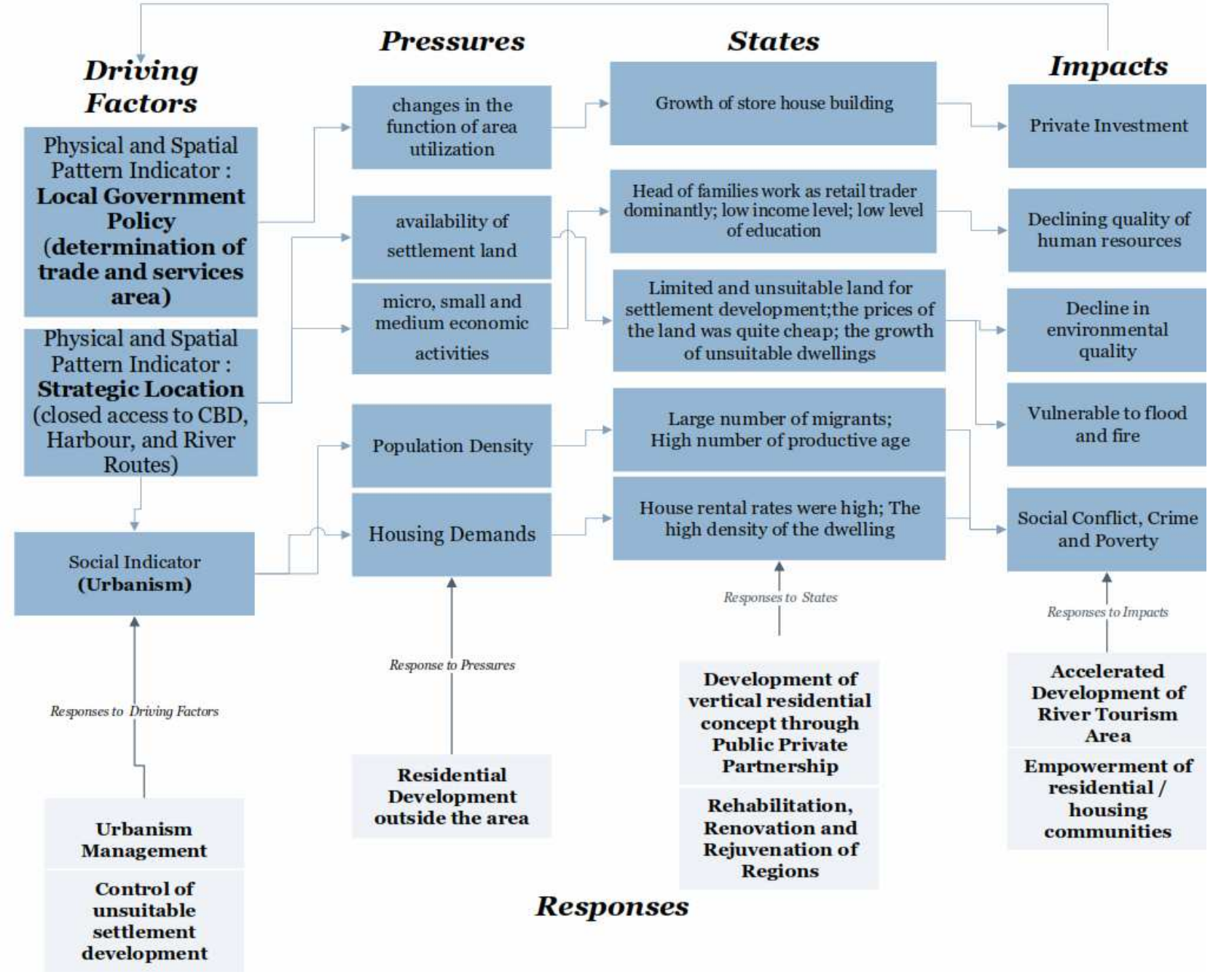

Fig. 5. DPSIR framework for slums on then riverbank (first priority).

In contrast to the research findings of Noorloos and Steel (2016) where social separation and exclusion were caused by the privatization and securitization of residential coastal settlements [58], the coastal area of Baubau City has been reclaimed but has not yet reflected the privatization of the investor/developer group. This is because the inhabitants of the coastal Baubau are mostly fishermen with a fairly high level of kinship. However, the potential for this separation due to privatization needs should be considered in the next 10 to 20 years, if there is no alignment with the existence of fisherman settlements (Fig. 6).

Traditional slums are the third priority with functional indicators being the driving factor and the main handling locus for optimizing regional functions. These factors put pressure on land use, the development of regional functions and the culture of 
traditional societies. Conditions (state) shown by the pressure include inadequate public utility infrastructure facilities, traditional house buildings inappropriate for habitation, land unsuitable for formal settlement development, and low level of settlement improvement.

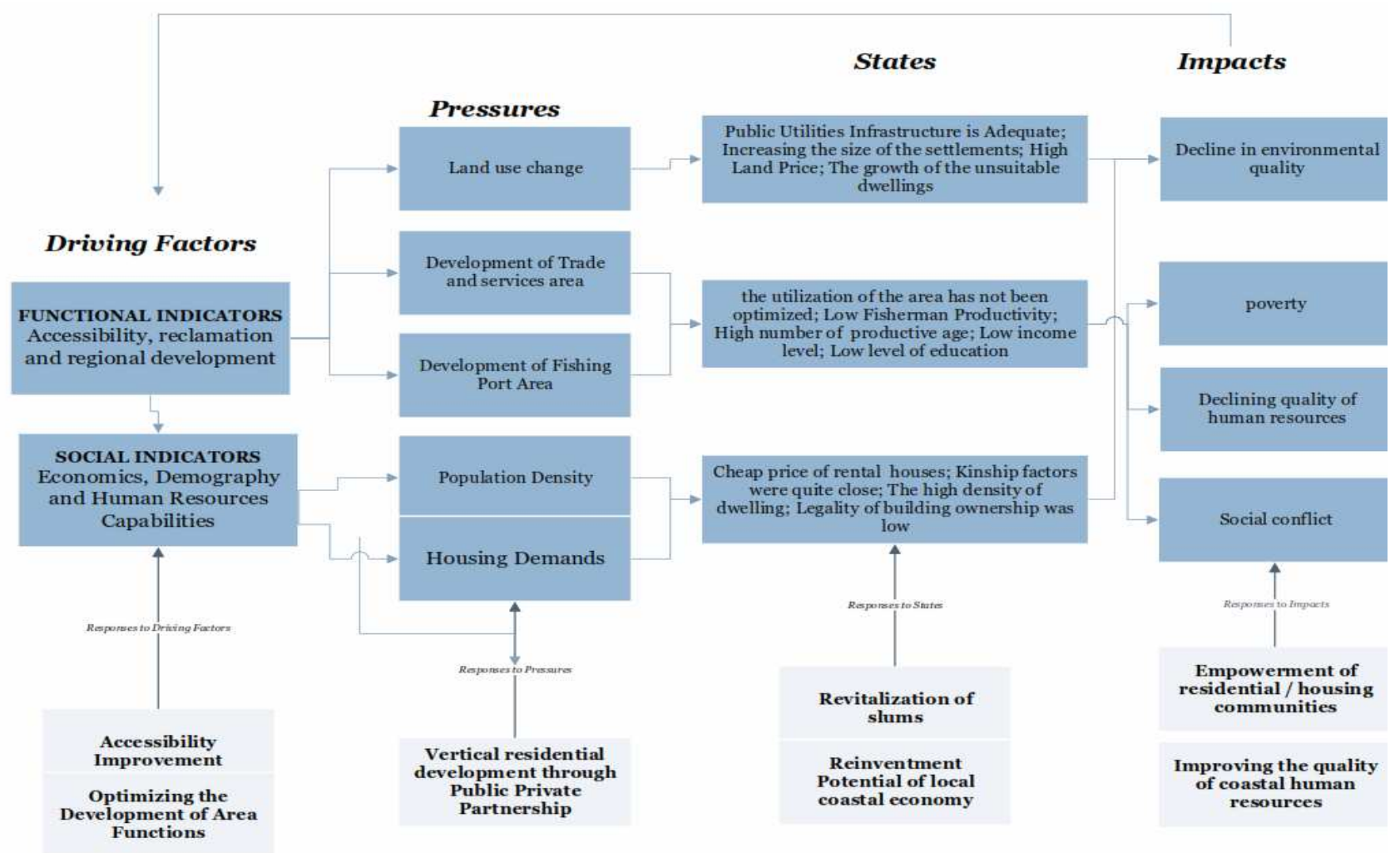

Responses

Fig. 6. DPSIR framework for slums on coastal areas (second priority).

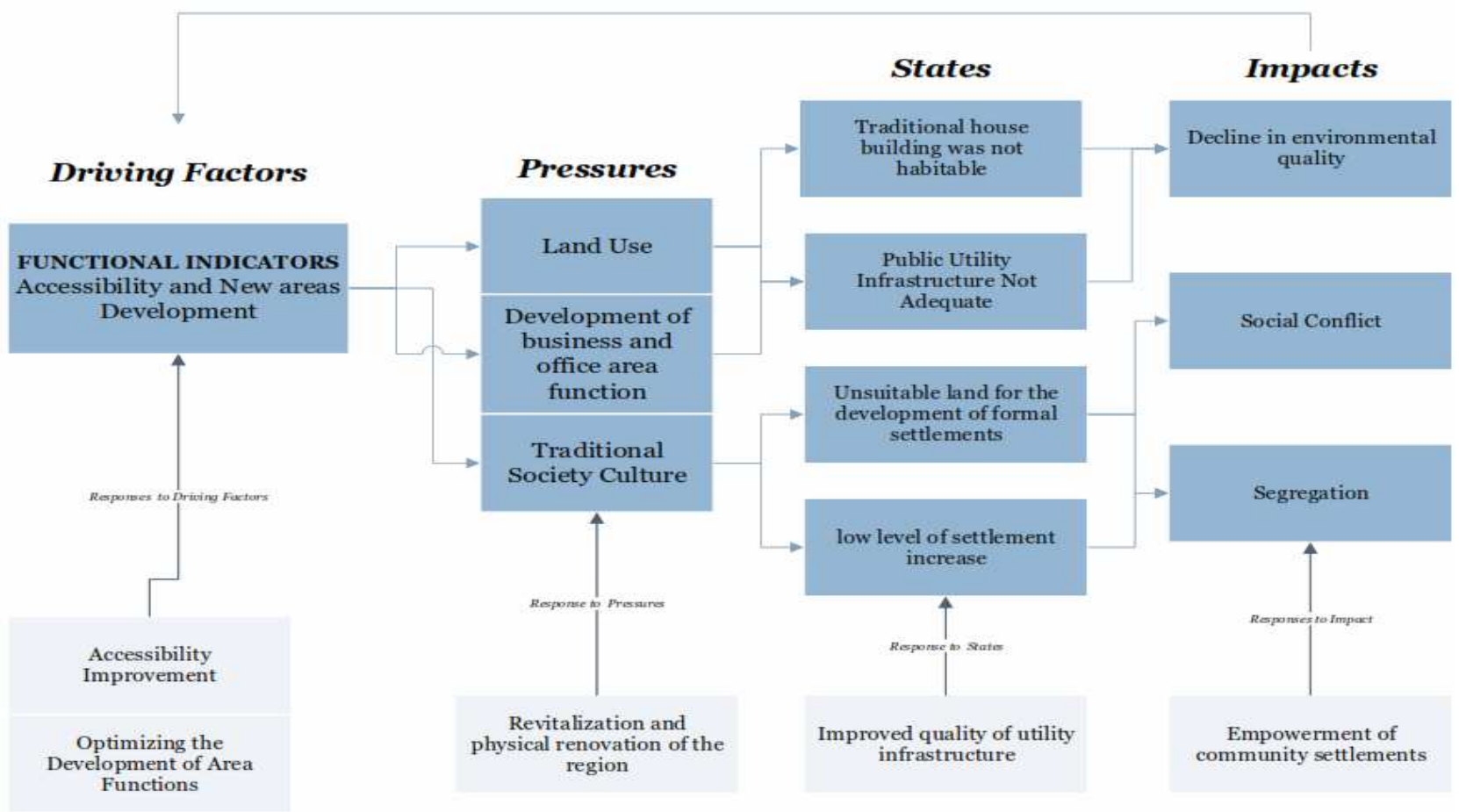

Responses

Fig. 7. DPSIR Framework for slums in traditional kampong (third priority).

These conditions have an impact on deteriorating environmental quality, social conflicts and potentially triggering segregation of settlements (impacts). Traditional community culture is an aspect 
that needs to be observed in this area. Traditional culture has a very strong influence on the distribution of settlements [24]. In line with the research conducted by Špačkováat al (2016), ethnic differentiation will lead to socio-spatial segregation, especially if local infrastructure policies are not pro-localist in the region [49]. Spatial planning practices should be conducted at an ideal level, organized, created, shaped, restructured, and designed to carry out the activities of all inhabitants [57]. It seems that the pattern of regional development set by the government does not support the condition of the local community. Although the area is also designated as a home industry development area, the policy has not been synchronized with the pattern of slum area management. By looking at the economic characteristics of the residents living in the area, the policy model (response) in the form of home improvement could be held by the residents themselves. In addition, the actions should be taken based on its driving factors, to increase accessibility, optimize the development of regional functions and empower settlement communities (see Fig. 7).

\section{CONCLUSION}

Slum management should consider appropriate models based on socio-spatial characteristics of regional typology. Taking into account the socio-spatial characteristics in the handling and management of residential areas, it will facilitate the decision-making process of the method to be used. The conditions and socio-spatial characteristics show that phenomena of living space in society can shape and change urban space including slums. Meanwhile, the space contained in the form of spatial planning policies and handling of physical slums often clashes with the real conditions of the society.

Besides considering the physical settlement of slum areas, the underlying factors causing the emergence of slums need to be examined. By using a combination of Fuzzy-MCDM and DPSIR framework, this model is expected to be used by urban planners. Based on the results of the research, we propose the following suggestions:

1) the government should consider the sociospatial factors behind the slum level according to the characteristics of each type of area;

2) programs/policies of slum area management should be synchronized with the policy of urban economic development and the policy of area development;

3) this research still needs to be continued by predicting the decline in the area of slums if this model is applied.. Coordinated multi-sectorial interventions and focus on handling and managing may be able to overcome urban problems and at the same time improve the urban welfare.

\section{ACKNOWLEDGEMENT}

The authors are deeply thankful to the National Development Planning Ministry of Republic Indonesia through Pusbindiklatren Research Grant, Baubau Local Government (Bappeda Baubau and Public Works Service) and Graduate School of Hasanuddin University, for providing data, funds, and other supporting facilities for this study.

\section{REFERENCES}

[1] Esch, T., Marconcini, M., Marmanis, D., Zeidler, J., Elsayed, S., Metz, A., Müller, A., Dech, S. (2014), Dimensioning urbanization - An advanced procedure for characterizing human settlement properties and patterns using spatial network analysis. In: Applied Geography, vol. 55, pp. 212-228. DOI: 10.1016/j.apgeog.2014.09.009

[2] Kanyinda, A. (2017), UN-Habitat Global Activities Report, Nigeria. Available online: https://unhabitat. org/global-activities-report-2017/

[3] Central Bureau of Statistics (2017), Baubau in Figures. Baubau City, Indonesia.

[4] Mukhija, V. (2001), Upgrading housing settlements in developing countries: The impact of existing physical conditions. In: Cities, vol. 18, no. 4, pp. 213-222.

[5] Wekesa, B. W., Steyn, G. S., Otieno, F. A. O. (2011), A review of physical and socio-economic characteristics and intervention approaches of informal settlements. In: Habitat International, vol. 35, no. 2, pp. 238-245. DOI: 10.1016/j.habitatint.2010.09.006

[6] Serageldin, M., Driscoll, J., Solloso, E., (2003), Partnerships and Targeted Programs to Improve the Lives of Slum Dwellers. UNCHS-Habitat International Conference on Sustainable Urbanization Strategies, Weihai, China, November 3-5.

[7] Sugiri, A. (2009), Financing Slum Upgrading in Indonesia: Can Sustainability Reinvestment Help?. Available online at: http://www.irbnet.de/daten/iconda /CIB_DC25424.pdf

[8] Purwanto, E., Sugiri, A. (2017), Determined Slum Upgrading: A Challenge to Participatory Planning in Nanga Bulik, Central Kalimantan, Indonesia. In: Sustainability, vol. 9, no. 7. DOI:10.3390 /su9071261.

[9] Sesotyaningtyas, M., Pratiwi, W. D., Setyono, J. S. (2015), Transformasi Hunian Dengan Perspektif Spasial Dan Tatanan Budaya: Komparasi Permukiman Kumuh Bang Bua, Thailand Dan Kampung Naga, Indonesia [Transformation Shelter With Spatial Perspective and Cultural Order: Comparison of Slum Residential Bang Bua, Thailand And Kampung Naga, Indonesia]. In: Geoplanning: Journal of Geomatics and Planning, vol. 2, no. 2, pp. 116-123. DOI: https://doi.org/10.14710/geoplanning.2.2.116-123 
[10] Srinivasan, S. (2005), Quantifying Spatial Characteristics of Cities. In: Urban Studies, vol. 39, no. 11, pp. 2005-2028. DOI: 10.1080/0042098022000011335

[11] Abbott, J. (2002), A method-based planning framework for informal settlement upgrading. In: Habitat International, vol. 26, no. 3, pp. 317-333. DOI: 10.1016/So197-3975(01)ooo50-9

[12] Yuliastuti, N., Saraswati, N. (2014), Environmental Quality in Urban Settlement: The Role of Local Community Association in East Semarang SubDistrict. In: Procedia - Social and Behavioral Sciences, vol. 135, pp. 31-35. DOI: 10.1016/j.sbspro.2014.07.321

[13] Rara, F., Said, D., Yuliastuti, N. (2013), The $3^{\text {rd }}$ International Conference on Sustainable Future for Human Security Mass housing sustainability based on community cohesion (A case study at Sendangmulyo, Indonesia). In: Procedia Environmental Sciences, vol. 17, pp. 814-821. DOI: 10.1016/j.proenv.2013.02.099

[14] Fahmi Fikri, Z., Hudalah, D., Rahayu, P., Woltjer, J. (2014), Extended urbanization in small and medium-sized cities: the case of Cirebon Indonesia. In: Habitat International no. 42, pp. 1-10. doi:10.1016/j.habitatint.2013.10.003

[15] Winarso, H., Hudalah, D., Firman, T. (2015), Peri-urban transformation in the Jakarta metropolitan area. In: Habitat International, vol. 49, pp. 221-229. DOI: 10.1016/j.habitatint.2015.05.024

[16] Surtiani, E. E. (2006), Faktor-Faktor Yang Mempengaruhi Terciptanya Kawasan Permukiman Kumuh Di Kawasan Pusat Kota (Studi Kasus: Kawasan Pancuran, Salatiga) [Factors Affecting the emerged of Slum Areas In City Center Area (Case Study: Salatiga)] Master Theses of Diponegoro University.

[17] Olthuis, K., Benni, J., Eichwede, K., Zevenbergen, C. (2015), Slum Upgrading: Assessing the importance of location and a plea for a spatial approach. Habitat International, vol. 50, pp. 270-288. DOI: 10.1016/j.habitatint.2015.08.033

[18] Mahabir, R., Crooks, A., Croitoru, A., Agouris, P. (2016), The study of slums as social and physical constructs: Challenges and emerging research opportunities. In: Regional Studies, Regional Science, vol. 3 , no. 1, pp. 399-419. DOI: 10.1080/21681376.2016.1229130

[19] Gottdiener, M., Budd, L., Lehtovuori, P. (2005), Key Concepts in Urban Studies, Sage Publication, London.

[20] Lefebvre, H. (1991), The Production of Space, vol. 29, pp. 454, Blackwell, Oxford.

[21] Fernández de Córdova, G., FernándezMaldonado, A. M., del Pozo J. M. (2016), Recent changes in the patterns of socio-spatial segregation in Metropolitan Lima. In: Habitat International, vol. 54, pp. 28-39. DOI: 10.1016/j.habitatint.2015.08.016

[22] Gu, C., Shen J. (2003), Transformation of urban socio-spatial structure in socialist market economies:
The case of Beijing. In: Habitat International, vol. 27, no. 1, pp. 107-122. DOI: 10.1016/S0197-3975(02) ooo38-3

[23] Yang, S., Wang, M. Y. L., Wang, C. (2015), Sociospatial restructuring in Shanghai: Sorting out where you live by affordability and social status. In: Cities, vol. 47, pp. 23-34. DOI: 10.1016/j.cities.2014.12.008

[24] Wu, Q., Cheng, J., Chen, G., Hammel, D. J., Wu, X. (2014), Socio-spatial differentiation and residential segregation in the Chinese city based on the 2000 community-level census data: A case study of the inner city of Nanjing. In: Cities, vol. 39, pp. 109-119. DOI: 10.1016/j.cities.2014.02.011

[25] Widiyastuti, D. (2013), Transformation of Public Space: Social and Spatial Changes A Case Study of Yogyakarta Special Province, Indonesia. Doctoral Theses of Dortmund University.

[26] Zwiers, M., Kleinhans, R., Van Ham, M. (2015), Divided Cities: Increasing Socio-Spatial Polarization within Large Cities in the Netherlands. In: IZA Discussion Paper series, no. 8882, pp. 1-31.

[27] Demirli, M. (2011), Socio-spatial Analysis of Urban Renewal In the Case of Relocating Kadifekale Inhabitants to TOKI Uzundere, Master thesis of The Graduate School of Social Science of Izmir University of Economics.

[28] Dupont, V. (2004), Socio-spatial differentiation and residential segregation in Delhi: $A$ question of scale? In: Geoforum, vol. 35, no. 2, pp. 157-175. DOI: 10.1016/j.geoforum.2003.08.003

[29] Michelini, J. J., Pintos, P. (2016), Metropolitan expansion and new socio-spatial segregation scenarios in contemporary Argentina. The case of Nordelta-Las Tunas (Buenos Aires). In: Habitat International, vol. 54, pp. 40-49. DOI: 10.1016/j. habitatint.2015.08.011

[30] Magsi, H., Torre, A. (2014), Proximity analysis of inefficient practices and socio-spatial negligence: Evidence, evaluations and recommendations drawn from the construction of Chotiari reservoir in Pakistan. In: Land Use Policy, vol. 36, pp. 567-576. DOI: 10.1016/j.landusepol.2013.10.009

[31] Lima, J. J. (2001), Socio-spatial segregation and urban form: Belem at the end of the 1990s. In: Geoforum, vol. 32, no. 4, pp. 493-507. DOI: 10.1016/So016-7185(01)00019-7

[32] Mattingly, K., Morrissey, J. (2014), Housing and transport expenditure: Socio-spatial indicators of affordability in Auckland. In: Cities, vol. 38, pp. 69-83. DOI: 10.1016/j.cities.2014.01.004

[33] Niedzielski, M. A., O'Kelly, M. E., Boschmann, E. E. (2015), Synthesizing spatial interaction data for social science research: Validation and an investigation of spatial mismatch in Wichita, Kansas. In: Computers, Environment and Urban Systems, vol. 54, pp. 204-218. DOI: 10.1016/ j.compenvurbsys.2015.09.004 
[34] Abbott, J. (2003), The use of GIS in informal settlement upgrading: Its role and impact on the community and on local government. In: Habitat International vol. 27 , no. 4, pp. 575-593. DOI: 10.1016/So197-3975(03)00006-7

[35] Detlef Baum, I. T., Vondroušová, K. (2014), Characteristics of Socio- spatial Segregation in Comparison of Two Cities (Halle - Ostrava). Research Report. University of Ostrava. Available online at: http://projekty.osu.cz/vedtym/dok/publikace/baum_ mesta.pdf

[36] Baja, N., Baja, S. (2014), Using Fuzzy Set Approaches in a Raster GIS for Land Suitability Assessment at a Regional Scale: Case Study in Maros Region, Indonesia. In: Modern Applied Science, vol. 8, no. 3, pp. 115-125. DOI: 10.5539/mas.v8n3p115

[37] Baja, S., Chapman, D. M., Dragovich, D. (2002), Using GIS-Based Continuous Methods for Assessing Agricultural Land-Use Potential in Sloping Areas. In: Environment and Planning. B- Urban Analytics and City Science, vol. 29, pp. 3-20. DOI: https://doi.org/10.1068/b2706

[38] Grekousis, G., Manetos, P., Photis Y. N. (2013), Modeling urban evolution using neural networks, fuzzy logic and GIS: The case of the Athens metropolitan area. In: Cities, vol. 30, no. 1, pp. 193203. DOI: 10.1016/j.cities.2012.03.006

[39] Grekousis, G., Fotis, Y. N. (2012), A fuzzy index for detecting spatiotemporal outliers. In: Geoinformatica, vol. 16, no. 3, pp. 597-619. DOI: 10.1007/s10707-011-0145-4

[40] Eraqi, A. M. Z. (2016), Development a Fuzzy Model to Predict the Index of Urban Development Priorities of the Parties to the Egyptian City in Partnership between the Cooperative Trinity. In: Procedia - Social and Behavioural Science, vol. 216, no. October 2015, pp. 129-140. DOI: 10.1016/j.sbspro. 2015.12.018

[41] Sarkar, S., Parihar, S. M., Dutta, A. (2016), Fuzzy risk assessment modelling of East Kolkata Wetland Area: A remote sensing and GIS based approach. In: Environmental Modelling and Software. vol. 75, pp. 105-118. DOI: 10.1016/j.envsoft.2015. 10.003

[42] Gigović, L., Pamučar, D., Lukić, D., Marković, S. (2016), GIS-Fuzzy DEMATEL MCDA model for the evaluation of the sites for ecotourism development: A case study of 'Dunavski ključ' region, Serbia. In: Land Use Policy, vol. 58, pp. 348-365. DOI: 10.1016/j.landusepol.2016.07.030

[43] Vahdat, K., Smith, N. J., Amiri, G. G. (2014), Fuzzy multicriteria for developing a risk management system in seismically prone areas. In: Socio-Economic Planning Sciences, vol. 48, no. 4, pp. 235-248. DOI: 10.1016/j.seps.2014.05.002

[44] Jeong, J. S., García-Moruno, L., HernándezBlanco, J., Sánchez-Ríos, A. (2016), Planning of rural housings in reservoir areas under (mass) tourism based on a fuzzy DEMATEL-GIS/MCDA hybrid and participatory method for Alange, Spain. In: Habitat International vol. 57, pp. 143-153. DOI: 10.1016/j.habitatint.2016.07.008

[45] Ness, B., Anderberg, S., Olsson, L. (2010), Structuring problems in sustainability science: The multi-level DPSIR framework. In: Geoforum, vol. 41, no. 3, pp. 479-488. DOI: 10.1016/j.geoforum.2009.12.005 [46] Ramos-Quintana, F., Ortíz-Hernández, M. L., Sánchez-Salinas, E., Úrsula-Vázquez, E., Guerrero, J. A., Zamorano, M. (2018), Quantitative-qualitative assessments of environmental causal networks to support the DPSIR framework in the decision-making process. In: Environmental Impact Assessment Review. vol. 69, pp. 42-60. DOI: 10.1016/j.eiar.2017.11.004

[47] Tscherning, K., Helming, K., Krippner, B., Sieber, S., Paloma, S. G. Y. (2012), Does research applying the DPSIR framework support decision making? In: Land Use Policy, vol. 29, no. 1, pp. 102110. DOI: 10.1016/j.landusepol.2011.05.009

[48] Liu, Y., Song, W., Deng, X. (2019), Understanding the spatiotemporal variation of urban land expansion in oasis cities by integrating remote sensing and multi-dimensional DPSIR-based indicators In: Ecological Indicators. vol. 96, part 2, pp. 23-37. DOI: 10.1016/j.ecolind.2018.01.029

[49] Špačková, P., Pospíšilová, L., Ouředníček, M. (2016), The Long-term Development of Sociospatial Differentiation in Socialist and Post-socialist Prague. In: Czech Sociology Review, vol. 52, no. 6, pp. 821-86o. Available online at: http://sreview.soc.cas.cz/ uploads/o337177fe41d6fea5e6o3bb2d5aafe91529d4c10 _16-6-04Pospisilova22.indd.pdf

[50] Tang, L., Ruth, M., He, Q., Mirzaee, S. (2017), Comprehensive evaluation of trends in human settlements quality changes and spatial differentiation characteristics of 35 Chinese major cities. In: Habitat International vol. 70, pp. 81-90. DOI: 10.1016/ j.habitatint.2017.10.001

[51] Jolliffe, I. T. (2002), Principal Component Analysis. In: Encyclopedia of Statistics in Behavioral Science vol. 30, no. 3, p. 487.

[52] Moraes, O. B., Abiko, K. (2008), Dweller perception using fuzzy logic for slum upgrading. In: Proceedings of the ICE - Municipal Engineer, vol. 161, no. 3, pp. 151-161. DOI: 10.1680/muen.2008.161.3.151

[53] Wieland, R. (2003), Fuzzy Models, vol. 1, no. April. Elsevier Inc.

[54] Daskalova, D., Slaev, A. D. (2015), Diversity in the suburbs: Socio-spatial segregation and mix in post-socialist Sofia. In: Habitat International vol. 50, pp. 42-50. DOI: 10.1016/j.habitatint.2015.07.007

[55] Jeong, J. H. (2011), From illegal migrant settlements to central business and residential districts: Restructuring of urban space in Beijing's 
migrant enclaves. In: Habitat International vol. 35, no. 3, pp. 508-513. DOI: 10.1016/j.habitatint.2011.02.003 [56] Du, J., Yang, Y., Li, D., Zuo, J. (2017), Do investment and improvement demand outweigh basic consumption demand in housing market? Evidence from small cities in Jiangsu, China. In: Habitat International vol. 66, pp. 24-31. DOI: 10.1016/ j.habitatint.2017.05.006
[57] Aminah, S. (2015), Konflik dan Kontestasi Penataan Ruang Kota Surabaya [Conflict and Contestation of Spatial Planning in Surabaya]. In: Masyarakat Jurnal Sosiologi, vol. 20, no. 80, pp. 59-79. [58] Van Noorloos, F., Steel, G. (2016), Lifestyle migration and socio-spatial segregation in the urban(izing) landscapes of Cuenca (Ecuador) and Guanacaste (Costa Rica). In: Habitat International, vol. 54, pp. 50-57. DOI: 10.1016/j.habitatint.2015.08.014 